We have received an article by Dr. Lawson Brown on the value of Lactagol (E. G. Pearson \& Co., Ld., 49, Watling St., London, E.C.). It gives a number of cases where the use of Lactagol greatly increased the supply of mother's milk. It is certainly to be tried in cases where an apparent want of milk is made a reason for depriving a child of nature's sustenance.

\section{Solvice eflotes.}

OF the extra pensions of $£ 100$ to officer's on the selected list (A. R. I., Vol. I, para. 734, and Seton and Gould's Manual, p. 118) for the Financial year 1913-14 one has been allotted to Lieut.-Colonel Henry K. Woolbert, M.B., F.R.C.S., Agency Surgeon who has been on leave out of India since 30th March 1912 and will retire on 30th June 1913, and the second Bengal establishment pension goes to Lieut.-Colonel J. R. Adie, M.B., who has been on leave out of India since 12th A pril 1912, and the pension will have effect from 22nd March 19i4. In Bombay Lieut.-Colonel J. Crimmin, v.C., c.I.E., retires on 2nd December 1913 on completing of 30 years' service for pension, and he will receive the Bombay special pension.

Up till now there is no claimant for the Madras special pension.

A GLANCe at the April Army list will show two vacancies on the selected list for Bengal and these have been filled up by the advancement of Lieut.-Col. G. F. W. Braide, I.M.S., Inspector General of Prisons, Punjab, and of Lieut.-Col. R. J. Marks, I.M.s., a Civil Surgeon in the United Provinces, both of whom have completed 26 years' service. These officers take the piace of Lieut.-Col. J. J. Pratt and Lieut.-Col. Cadell, retired.

In Bengal, however, a few more vacancies must soon occur by the long deferred promotion of Lieut.-Col. Drury, the I G. C. H. of Bihar, the retirement of Lieut.-Col. Woolbert in June 1913, and early in 1914, by the retirements of Lieut.Col. Adie and Colonel Neil Campbell, C.B., C.I.E.

In Bombay Lieut.-Col. M. A. T. Collie retires on 29th June 1913. In Madras there will be a vacancy on 29th June by the retirement of Col. H. St. C. Carruthers as I. G. C. H., Burma.

Colonel G. F. A. Harris, C.S.I., F.R.C.P., I.M.S., having gone on 7 months, furlough ; Colonel W. R. Edwards, c.M.G., I.M.s., acts as Inspector-General of Civil Hospitals, Bengal, with effect from 11th April 1913.

Lieutenant.Colonel C. R. Green, F.R.C.S., I.M.S., Professor of Midwifery at the Medical College, Calcutta, having gone on 8 months' furlough, his place is taken by Major Holdich Leicester, M.D. (London), M.R.C.P., F.R.C.s. (England), who comes in from Bihar and Orissa, where since his return from leave he has been a Civil Surgeon.

Surgeon-General Sir Colvin Colvin-Smith, k.C.B., Madras Medical Service, (retired), died at his residence, 5, Cresswell Gardens, South Kensington, on Saturday, 1st March 1913. He was the son of the late Revd. Robert Smith, D.D., of Aberdeen, and was born on 4th August 1829, educated at King's College, Aberdeen, where he took the $M . D$ in 1851, also the L.R.C.S. of Edinburgh in 1850, and entered the Madras Medical Service as Assistant-Surgeon on 3rd November 1851. He became Surgeon on 14th December 1864, Surgeon-Major on 3rd November 1871, and Deputy Surgeon.General on 5th Angust 1879; retiring with a step of honorary rank on 29th September 1884. He had a long list of war service, beginning with the second Burmese War in 1852-53, when he served in the operations before Rangoon in April 1852, at the capture of the White House Stockade and of the Shwe Dagon Pagoda, and the occupation fo Prome, receiving the medal and clasp. In the Mutiny he served from 1857 to 1859 , with the Kampti Moveable Column, and with the Sagar Field Division, taking part in the affairs at Khoni Pass, Narain pur, Nimkaira, Budgam, and other minor skirmishes on the Great Dekkan road ; also in operations in the Palamau district, and in the march to Jabalpur, and received the Mutiny me al, with a clasp. When serving as Deputy Surgeon-General of the Haidarabad Subsidiary Force and Haidarabad Contingent, he was appointed PrinciForce and War in 1882; took part in the Battle of Tel-el-Kebir, and in the forced march to and occupation of Zagazig. He was mentioned in despatches in the London Gazette of 17th November 1882, and received the Egyptian medal with a clasp, the Khedive's bronze star, the third class of the Osmanieh, and the C.B. He was also appointed an Honorary
Surgeon to the Queen on 5th July 3899, received a good service pension on 18th January 1903, and was promoted to K.C.B on 26 th June 1903 .

Is the London Gazette of 4th March Sir Richard Havelock Charles, G.c.v.o., is granted the temporary rank of SurgeonGeneral, dated 28th February 1913, while holding the office of President of the Medical Board, India Office.

The publication of the second supplement to the Dictionary of National Biography, containing notices of men of importance who have died between 1901 and 1911, has now been completed. Short lives of the following I.M.S. men are included.

Vol. I.-Surgeon-General J. M. Cunningham, by D'Arcy Power.

Vol. II.-Sir Joseph Fayrer, by H. P. Cholmeley, M.D.

Sir William Guyer Hunter, by D'Arcy Power.

W. W. Ireland, by D'Arcy Power.

Sir George King, by Sir David Prain

Vol. III.-Dr. William Smoult Playfair, by H. D. Rolleston.

Major Frank Dennis Browne, of the Madras Medical Service, died of pneumonia at Naushahra on 19th February 1913. He was born on 26 th October 1869, educated at Leeds and Newcastle, took the M.B., Durham, with Honours in 1893, and entered the I.M.S. as Surgeon Lieutenant on 29th July 1896 , being one of the last batch commissioned to the separate Presidential Services. The next batch were the first on the General Service list. He became Captain on 29th July 1899. and Major on 29th January 1908. Most of his service had been spent in military employ, but he acted for some time. a few years ago, as Civil Surgeon of Port Blair, in the Andaman Islands. His regiment was the 112th Infantry, formerly the 12th Bombay Infantry. The Army List assigns him no war service.

IT has been decided that Indian Military Law will no longer be taught at the R. A. M. C. School, but instruction will be carried out regimentally in India.

THE Secretary of State has sanctioned the creation of a whole-time Professor of Pathology at the Grant Medical College, Bombay. This is a new I. M. S. appointment. and does away with the old system under which the chair of Pathology was held by the 2nd Physician J. J. Hospital.

AT the same time the 2nd Surgeon J. J. Hospital', will no Ar the Professorship of Ana. tomy, which it is intended should in future be a whole-time appointment to be filled, if possible, in India, from outside the ranks of the Indian Medical Service.

THe Secretary of State has decided that, while held by I. M. S. officers, appointments in the Bacteriological Department shall be regarded as cadre ones.

IDEntity DISCS.-With reference to India Army Orders No. 403 of 1908 and No. 110 of 1910 , it is notified for information that the is notified for information that the the issue of identity discs with cords to such of the officers noted below, as have not already received a free issue

lettar No, 5844-1 (Q.M.

G. 8 ) dated 13 th Fobru ary 1913 .

\section{at Home :-}

Staff Officers.

British officers with British and Indian units, including the Supply and Transport Corps.

Indian Officers.

Officers of the Royal Army Medical Corps.

, ," Indian Medical Service.

," ," , "Army Veterinary Corps

", , ," Ordnance Department.

2. The first issues will be free. Thereafter the articles will be kept up at the expense of the officers.

3. Discs with cords will be issued to regimental officers from the reserves maintained in their units, the reserves being replenished by including the numbers issued in requisitions on Army Clothing Factories. Issues to Staff officers and those in Departments will be made on requisition from Army Clothing Factories.

4. The discs of regimental officers will be marked regimentally, and those of other officers in Army Clothing Factories. When demanding discs ready marked from Clothing Factories, officers concerned should give complete information 
regarding the marking required, vide India Army Order No. 403 of 1908 .

5 . A further notification will be published when factories will be able to supply discs with cords.

Captain C. A. F. Hingston, I.M.S., is due back from furlough on Sth May.

Captain M. J. QUIRKE, I.M.S., is due from combined privilege and study leave on 28 th May.

Captain H. Stott, I.M. S., reported for duty as Surgeon to H. E. The Governor of Madras on 4th February.

MAJOR A. G. McKendRICK, I.M S., was granted two years combined furlongh and study leave and is not due out till 23rd February 1915.

HIs Excellency the Governor of Bombay in Council is pleased to appoint Assistant-Surgeon Yashavant Govind Nadgir, L. M. \& S., to act a Civil Surgeon, Bijapur, during the absence, on deputation, of Captain M. S. Irani, I.M S., or pending further orders.

THE Director-General, I.M.S, has issued the following memo. :-

"Indian Medical Service officers in Civil employment desirous of obtaining non-entitled indulgence passages for themselves and their families, should submit their application on I. A. F. Y. - 1727 direct to the General Officer Crmmanding of the Port of Embarkation at Bombay or Karachi."

Oaptais F. P. Wernicke, M.B., I.M.s., acts as Civil Surgeon, Pachmarhi, during the season of 1913.

Captain W. J. Powell, I.M.S., on general duty, is appointed to act as Superintendent, Central Jail, Jubbulpore.

MAJOR C. H. BensLey, I.M.S., is appointed to the Central Jail, Nagpur.

Captain W. J. Fraser, m.B., ch.b., F.r.c.s., i.m.s., Civil Surgeon. Chhindwara, is deputed to undergo a course of instruction in Malariology at Delhi.

MaJor V. H. Roberts, F.R.C.S.. I.M.S. Civil Surgeon, Seoni, is placed in visiting medical charge of the Chhindwara District.

Third Class Military Assistant-Surgeon A. R. Emmett Sub-Divisional Medical Officer. Ellichpur. Amraoti District, is deputed to undergo a course of instruction in Malariology at Delhi.

Coronet W. G. Krisg, C.I.F., I.M.s. (retired), late Sanitary Commissioner with the Government of Madras, has been appointad lecturer in Applied Hygiene in the Tropics to King's College, University of London.

THe following changes in Burma are gazetted :-

On his relief by Mr. F. X. D'Attaides, L.M. \& s. (Bomb.), On Military Assistant Surgeon, and Honorary Liente Senior Military Assistant \& s. (Mad.), L.R.C.P. \& s. (Edin.), nant L. K. Rodrigues, is appointer to be Civil Surgeon. Falam, Givil Surgeon, Katha, Military Assistant-Surgeon and Honorary in place of Senior Military Assistant-Sing

SEcond Class Military Assistant:Surgeon H. T. I. Duck. worth is appointed to be a Civil Surgeon permanently, with worth is appointe' $\mathrm{rd}$ May 1910, consequent on the reversion of effect from Class Military Assistant-Surgeon H. J. Willes to a subordinate charge.

First Class Military Assistant-Surgeon W. L. Brookes is Finst Class Military Assistant-Surgeon
appointed to be a Civil Surgeon permanently, with effect appointed to be a Civil Surgeon pert on the retirement of from the 13th June 1912, consequent on Honorary Major A. H. Nolan.

THE services of Captain Ba Ket, M.B., I.M.S., an Officiating THE services of Captain Ba replaced at the disposal of the Civil Surgeon in Burma,
Captarn H. B. ScotT, I.M.S., Officiating Resident Medical Officer, General Hospital, Rangoon, is appointed to be Resident Medical Officer, General Hospital, Rangoon, sub pro tem., with effect from the 7th November 1912, in place of Major H. A. Williams, D.s.o., I.M.S., transferred.

Major P. F. Chapman, I.M.s., Civil Surgeon, who was granted combined leave by Order No. 487, dated the 7 th March 1912, was on study lenve from the 14th October 1912 to the 31st January 1913.

Major A. M. Flening, I.M.s., Civil Surgeon, who was granted combined leave by Orders No 2042, dated the 14th November 1911, and No. 1379, dated the 20th July 1912, was on study leave from the 2nd to the 31st December 1912 (thirty days).

EIGHT months' furlough is granted to Captain A. E. Grisewood, I. M.S., Chief Plague Medical Officer, Central Provinces, with effect from the 12th March 1913, or the subsequent date.

ON return from the combined leave granted him the services of Major W. H. Kenrick, L.R.C.P., M.R.C.S., D.T.M., I.M.S., are placed at the disposal of the Sanitiry Commissioner, Central Provinces, for employment on Malaria Survey duty in the Central Provinces.

Lieutenant-Colonel J. T. Calvert, M.B., M.R.C.P. D.P.H., I.M.S., Principal and Professor of Medicine, Medical College, Calcutta, and First Physician to the College Hospital is, with effect from the afternoon of the 7th Narch 1913, granted privilege leave for three months combined with furlough for six months in continuation.

Lieutenant-Colonel B. H. Deare, M.R.C.P., D.'.H., I. M.s., is appointed to officiate as Principal and Professor of Medicine, Medical College; Calcutta, and First Physician to the College Hospitai, during the absence, on leave, of Lieutenant-Colonel J. T. Calvert, M.B., M.R.C.P., D.P.H., I.M.S.

MAJOR D. MCCAY, M.D., M.R C.P., I.M.S., Professor of Physiology, Medical College, Calcutta, is appointed to officiate as Professor of Materia Medica, Medical College, Calcutta, and Second Physician to the College Hospital, during the absence of Lieutenant-Colonel B. H. Deare, M.P.C.P., D.P.H., I.M.S, on other duty.

Dr. W. C. Hossack, Health Officer of the Port of Calcutta, has been allowed privilege leave combined with furlough for six months.

Dr. C. Banks, Protector of Emigrants, Calcutta, and Superintendent of Emigration, is appointed to act as IIealth Officer of the Port of Calcutta, in addition to his own duties. during the absence, on leave, of Dr. IV. C. Hossack, or until further ordèrs.

Caprain D. P. Goll, I.M s., Civil Surgeon, Mymensingh, has been allowed privilege leave combined with study leave and furlough for two years and eight months. .

MAJor M. MACKELVIE, I.M.S.; has been granted by $\mathrm{His}$ Majesty's Secretary of State for India, an extension of leave for five months, viz., study leave for three months and furlough for two months.

THE services of Major H. M. Mäckenzie, I.M.S., are replaced at the disposal of the Government of India in the Home Department, with effect from the date on which he relinquishes charge of his duties in the Bahawalpur State.

CAPTAIN C. F. MARR, I.M.S., has beeu granted an extension of leave on private affairs.

Captain. A. K. Munro, I.M.s., is appointed to the substantive medical charge, 128 th Pioneers, vice Captain IV. J. Fraser, I.M.S., and Captain A. G. Wells, R.A.Mr:c., specialist in operative surgery, 3rd (Lahore) Division, from March 25th, 1913.

Lieut.-Colonel R. H. Elliot, I.M.S., has an interesting article in The Ophthalmoscope on the use and mn nagement of self lit ophthalmoscopes in use in the Madras clinic. 
Captain T. C. Boyd, I.M.S., F.R.c.s.I., has taken the D. P. H. of the Royal Colleges of Physicians and of Surgeons, Ireland.

Is modification of so much of Government Notification No. 2031, dated the 11th March 1913, as relates to the appointment of Lieutenant-Colonel A Street, M.B. (Cantab.), F.R.C.S., I.M.S., His Excellency the Governor of Bombay in Council is pleased to appoint that officer, with effect from the 15th idem, Acting Senior Medical Officer, J. J. Hospital, and sub. protem. Principal, Grant Medical College in sub. stantive addition to his own duties, pending further orders.

With reference to Government Notification No. 1986, dated the 10th March 1913, His Excellency the Governor in Council is pleased to appoint Assistant-Surgeon Mancherji Jamaspji Mi istri, L.M. \& S., to act as Civil Surgeon, Surat, in addition to his own duties, from the date of departure on leave of Major J. H. McDonald, M.B., C.M. (Edin.), I.M.S., pending the arrival of Major R. W. Anthony, M.B., C.M. (Edin.), F.R.C.s. (E.), I.M.S.

MAJOR T. STODART, M.B., is promoted to be LieutenantColonel, I. M. S., with effect from 30 th January.

Senior Assistant-Surgeon and Honorary Lieutenant Henry Lovell William Clark is removed from the service, with effect from 10th March 1913.

He was hanged for the Agra murders on 26th March.

THE services of the undermentioned officers are placed permanently at the disposal of the Government of Madras: Captain L. Hirsch, M.R.C.S., L.R C.P., I.M.S.

Captain D. S. A. O'Keeffe, M.B., B.ch., I.M.S.

Captain A. C. Ingram, M.D., I.M.S.

MajoR J. H. MCDonaLD, M.B., C.M. (Edin.), I.M.s., is granted, from the 19th March 1913, or the subsequent date of relief, such privilege leave of absence as may be due to him on that date in combination with furlough for such period as may bring the combined period of absence up to eighteen months.

HIS Excellency the Governor of Bombay in Qouncil is pleased to make the following appointments :-

Lieutenant-Colonel C. T. Hudson, I.M.S., on return from leave, to be Civil Surgeon, Dhárwár.

Major R. W. Anthony, M B., C.M. (Edin.), F.R.C.S. (E.) I.M.S., to do duty as Civil Surgeon, Surat, vice Major J. H. McDonald, M.B., c.M. (Edin.), I.Mr.S., proceeding on leave.

Lieutenant-Colonel W. E. Jennings, M.D., C.M. (Edin.), D.P.H. (Dub.), I.M.S., having gone on deputation to learn work of P. M. O. in the Military Department, the following officiating appointments are gazetted:-

Lieutenant-Colonel J. Crimmin, v.C, C.I.E., D.P.H. (Ire.), I.N.S., to act as Health Officer of the Port of Bombay.

Lieutenant-Colonel S. H. Burnett, M.B., c.M. (Abdn.), I.M.s., to act as Presidency Surgeon, 'Third' District, and in medical charge of the Common Prison, House of Correction and Byculla Schools, in addition to his own duties.

HIs Excellency the Governor of Bombay in Council is pleased to make the following appointments, vice LieutenantColonel C. H. L. Meyer, M.D., B.S. (Lond.), I. M.S., retiring (15th March 1913) :-

Lieutenant-Colonel A. Street, M. B. (Uantab.), F.R.C.S. I.M.S., to act as Senior Medical Officer, J. J. Hospital, and Principal, Grant Medical College, in addition to his own duties, pending further orders.

Major E. F. G. Tucker, M.B., B.S., M.R C.P. (Lond.), I.M.S. to be Second Physician and Registrar, J. J. Hospital, but to act as First Physician, J. J. Hospital, and Professor of Medicine and Clinical Medicine and Therapeutics, Gran Medical College, during the absence of Lientenant-Colonel L. F. Childe, M B. (Lond.), I.M.S., or pending further orders. Captain R. M. Carter. F.R.C.S., D.T.M. M. (Liverpool), I.M.S. to act as Second Physician and Registrar, J. J. Hospital, and Professor of Pathology, vice Major E. F. G. Tucker, I.M.S., pending further orders.

Captain A. J. V. Betts, M.B. (Lond.), I.M.S., on return from leave, to be Resident Surgeon, St. George's Hospital, and Professor of Materia Medica and Pharmacy, Grant Medical College.
THE following notifications are taken from the Burma Gazette:-

Privilege leave for three months combined with furlough for one ye $u$, and study leave for nine months, is granted to Captain R. D. Saigol, I.M.S., with effect from the date on which he may avail himself of the privilege leave.

MaJor J. GOOD, I,M.s., was granted by His Majesty's Secretary of State for India, study leave from the 1st October 1912 to the 31st December 1912.

THE Lieutenant-Governor accepts the resignation of his appointment tendered by Civil Assistant-Surgeon Hussain Buksh, L.R.C.P. \& s. (Edin.), L.F.P. \& s. (Glas.), with effect from the 18th March 1913, or the subsequent date on which he may be relieved of his duties.

Privilege leave for three months and furlough out of India for four months in continuation thereof are granted to First C ass Military Assistant-Surgeon E. J. Murphy, with effect from the date on which he may avail himself of the privilege leave.

ON his relief by Mr. F. X. D'Attaides, L.M. \& s. (Bom.), Senior Military Assistant-Surgeon and Honorary Lieutenant I. K. Rodriguez, L. M. \& s. (Mad.', L.R.c.P \& s. (Edin:), Civi Surgeon, Katha, is appointed to be Civil Surgeon, Mônywa, in place of First Class Military Assistant-Surgeon E. J. Murphy, proceeding on leave.

Lieutenant-Colonel R. H. Elliot, F.R.C.S., I.M.S., has been granted one month and 18 days' privilege leave on or after 2 nd May 1913.

MAJOR S. A. RUzZaK, I.M.S., is due oūt from furlough on 11th June 1913 .

Captain P. L. O'Neil, I M.S., has been granted 18 months combined and study leave.

THE promotion of Major Thomas Stodart, M.в., to that rank is antedated from the 29 th July 1905 , as notified in the London Gazette of the 15th May 1906, to the 30th Jannary 1905.

The promotion of Major Herbert Armstrong Williams, D.s.o., M.B., to that rank is antedated from the 27 th January 1912 , as notified in the London Gazette of the 22nd March 1912 , to the 27 th July 1911 .

THE following are promoted to be Senior Assistant-Surgeons with the Honorary rank of Lieutenant from 7 th December 1912:-

1st Class Assistant-Surgeon James Francis Fleming.

1st Class Assistant-Surgeon Edwin Joseph Murphy.

1st Class Assistant. Surgeon Robert Gunn Babonau.

1st Class Assistant-Surgeon Harry George Charles Mills.

1st Class Assistant-Surgeon Edward Gerald Alfred Prins.

THE services of Captain F. W. Sumner, M.B., F.R.C.S.E., I.M.S., are placed permanently at the disposal of the Government of the United Provinces.

Lieutenant-Colonel H. B. Meiville, I.M.s., officiating chief plague officer, United Provinces, to be confirmed in that appointment, with effect from the 20th February 1913.

Captír J. S. O'NeILL, I.M.S., supervising medical officer, travelling dispensaries, Benares, is placed on special, plague duty at Lucknow until further orders.

Lifutenant-Colonel P. J. Freyer, M.D., I.M.s. (retd.) of St. Peter's Hospital for stone, has-been appointed on the Honorary Consulting Staff of the Queen. Alexandra Military Hospital, London, the only service man so appointed.

THe following changes have been ordered in Bihar and Orissa :-

Lieutenant-Colonel R. Maddox, I.M.s., returns to Ranchi from Gya, his place at Gya is taken by Major A. F. Stevens, I.M.S., from Hazaribagh ; Lieutenant-Colonel Jordan, I M.S., goes to Hazaribagh as Civil Surgeon and Major J. W.'. Megaw, on return from furlough, is posted to Monghyr. Major V. Lindesay, I.M.S., from Ranchi has gone on furlough 
Military Assistant-Surgeon C. Mullins is confirmed as a Civil Surgeon in Assam, with effect from 1st June 1912.

Surgeon-General A. M. Crofts, c.I.e., Indian Medical Service, Deputy Director, Medical Services, 2nd (Rawalpindi) 1)ivision, has been appointed to officiate as Director-General, Indian Medical Service, during the absence, on leave, of the Hon'ble Surgeon-General Sir C. P. Lukis, K.C.S.I., M.D., F.R.C.S., I.M.S., or until further orders.

Captain M. A. Nicholson, M.B., Indian Medical Service, to be Medical Officer, Lawrence Military Asylum, Sanawar, vice Captain N. S. Simpson, Indian Medical Service, vacated, with effect from the 13th February 1913.

THE undermentioned officers of the Indian Medical Service, laving completed their courses at the Royal Army Medical College and at Aldershot, have been finally admitted to the service. Their commissions will bear date the 27 th July 1912 :-

John Dykes Wilson, M.B.

Laurence Allfrey Pelham Anderson.

William Calder Paton, M. B.

James Bennett Hance, M. B.

Stephen Gordon.

Harold Kirkby Rowntree, N.B.

Graham Yalden Thomson, M.B.

Basil Franklin Eminson, M. B.

Anthony Kennedy.

Sorab Dhunjibhoy Ratanagar.

Colin McIvar.

WITH reference to the Notifications quoted in the margin A rni Department the promotion of Major Williain Notification No 282, Hamilton Kenrick. I.M.S., published in dated the 7th April 1911. Army Department Notification No. 132, Army Depurtment dated the 12th February 1909, is Notification No. 822, antedated from the 28th January 1909 dated the 29th Septem: antedated fo the 29th July 1908. ber 1911 .

Military Assistant-SurgeON L. V. Jaensch, I.S.M.D., assistant to Civil Surgeon, Naini Tal, to be a Civil Surgeon, with effect from the 16th February 1913, vice Captain F. G. Fox, retired, and to be posted to Hardoi.

Major J. N. Walker, I.M.S., Civil Surgeon, from Rae Bareli to Aligarh.

MaJor H. W. ILLIUS, I.M.S., Officiating Civil Surgeon, from Budaun to Rae Bareli.

Civil Assistant-Surgeon Lachmi Narayan Rai, attached to sadr dispensary, Bijnor, to hold civil medical charge of the district, in addition to his own duties, vice Captain V. B. Nesfield, I.M.s.

THE Civil Surgeon of Moradabad to hold visiting medical charge of the Bijnor district, vice Captain V. B. Nesfield, I.M.S.

Major G. Hutcheson, I.M.S., Civil Surgeon, Aligarh, has been granted privilege leave combined with study leave and furlough for a total period of twenty months, from the 1st April 1913, or subsequent date.

MAJOR E. L. PerRy, I.M.s., chief malaria medical officer, Punjab, was granted 7 months' combined privilege and study leave, with effect from 5th March.

Captain N. S. Simpson, I.M.S., whose services have been temporarily pliced at the disposal of this Government by the Government of India, to be employed on plague duty in the Benares circle, vice, Captain J. S. O'Neill, I.M.S.

Military Assistant-Surgeon G. S. Jennings, I.s.M.D., MILITARY AsSISTANT-SURGEON G. ST the disposal of this
whose services have been placed at the Government, to be steward at the King George's Medical College, Lucknow,
WITH effect from the 27th December 1912, LieutenantColonel W. Vost, I.M.s., to be a Civil Surgeon of the 1st class, vice Lieutenant-Colonel J. J. Pratt, I.M.S., retired.

Witu effect from the 27 th Dece mber 1912, Captain F. W. Sumner, I.M.S., Civil Surgeon, 2nd class, sub. pro tem., whose services have been perman ently placed at this Government's disposal by the Government of India, Home Department, to be confirmed in that appointment, vice Lieutenant. Colonel W. Vost, I.M.S.

AT a recent meeting of the Indian Research Fund, held at Delhi, it was decided among other matters, that Major E. D. IV. Grieg, I.M.S., will continue his cholera enquiry for another year, Captain Mackie, I. M.S., will proceed with the enquiry into Kala Azar, Captain Cunningham, I.M.s., will undertake the enquiry into the prevalence of dysentery in Bengal jails and the Andamans, and Major Hutchinson, I. M.s., will take up the bacteriological analysis of water.

IT is understood that in future the tenure of the posts of Civil Surgeon at Ranchi and at Hazaribagh will be for 3 year's only.

THE following notification by the Government of India in the Department of Education is republished:-

The services of Captain T. C. McCombie Young, M.в., I.M.S., are placed permanently it the disposal of the Chief Commissioner of Assam with a view to his confirmation in the Sanitary Department, with effect from the 6th Novem. ber 1909 .

CAPTAIN C. F. MARR, I.M.s., acts as medical storekeeper, Lahore, vice Major Gibbs, I.M.s.

Lirut. J. F. H. Morgan, I.M.S., resigns the service. His first commission was dated 23th January 1911 and he was given leave out of India on 10th September last.

\section{Alotice.}

Scientific Articles and Notes of interest to the Profession in India are solicited. Contributors of Original Articles will receive 25 Reprints gratis, if requested.

Communications on Editorial Matters, Articles, Letters and Books for Review should be addressed to THE EDITOR, The Indian Medical Gazette, c/o Messr's. Thacker, Spink \& Co., Calcutta.

Communications for the Publishers relating to Subscriptions, Advertisements and Reprints should be addressed to The Publishers, Messrs. Thacker, Spink \& Co., Calcutta.

Annual Subscriptions to "The Indian Medical Gazette," Rs. 12, inckuding postage, in India. Rs. 14, including postage, abroad.

\section{BOOKS, REPORTS, \&c., RECEIVED :-}

J. B. Murphy's Eurgical Clinics (As. 8). W. B. Saunder \& Co. Lee' Obstetrics. W. B. Saunder \& Co.

Punjab Administration Report.

R. W. Allen's Bacterial Diseases of Respiration.

J. B. Hurry's Vicious Circles in Disease. J. \& A. Churchill (2nd Ed.)

L. 'Williams' Minor Maladies, 3rd Ed. Price $5 s$. Bailliere, Tindall \& Cox.

Hooker's Chloride of Lime in Sanitation. New York, J. Wiley \& Sons. Hooker's Chloride of Lime in Samit.

Loudon, Chapman i Hall, Ld. W. Hanna's Studies in Vaccination. Price 7s.

U. S. Public Health Bulletins, Medical Zoology. No. 85 . International Clinics, 4 Vols., 1912

International Clinics, 4 Vols., 1912. 1913. 16s.

Cammidge' Electro-therapeutics. Longmans Greon. \& Co. $8 s .6 d$. net Fitzsimon's Snakebite \& Treatment. Longmans, Green \& Co.

\section{LETTERS, COMMUNICATIONS, \&c., RECEIVED FROM:-}

Lt.-Col. Nott, I.M.s., Howrah; Major Clayton Lane, I.Mr,s., Berham. Lt.-Col. Nott, I.M.s., Howrah ; Major ; Major Delany, I.M.s., Chapra; pur; Coses, r.m.s., Calcutta; Lt.-Col. Barry, r.M.S., Rangoon; Lt.-Col. Sitherland, 1.M.s., Calcutta; Lt.Col. C. Mine, Major F. L. Hammond, He.M.s., Mandalay ; Lt.-Col. Bruce Seton, I.M.s., Simla, 